\title{
OCEANA

No Time to Lose:

Last Chance for Survival

for North Atlantic

Right Whales

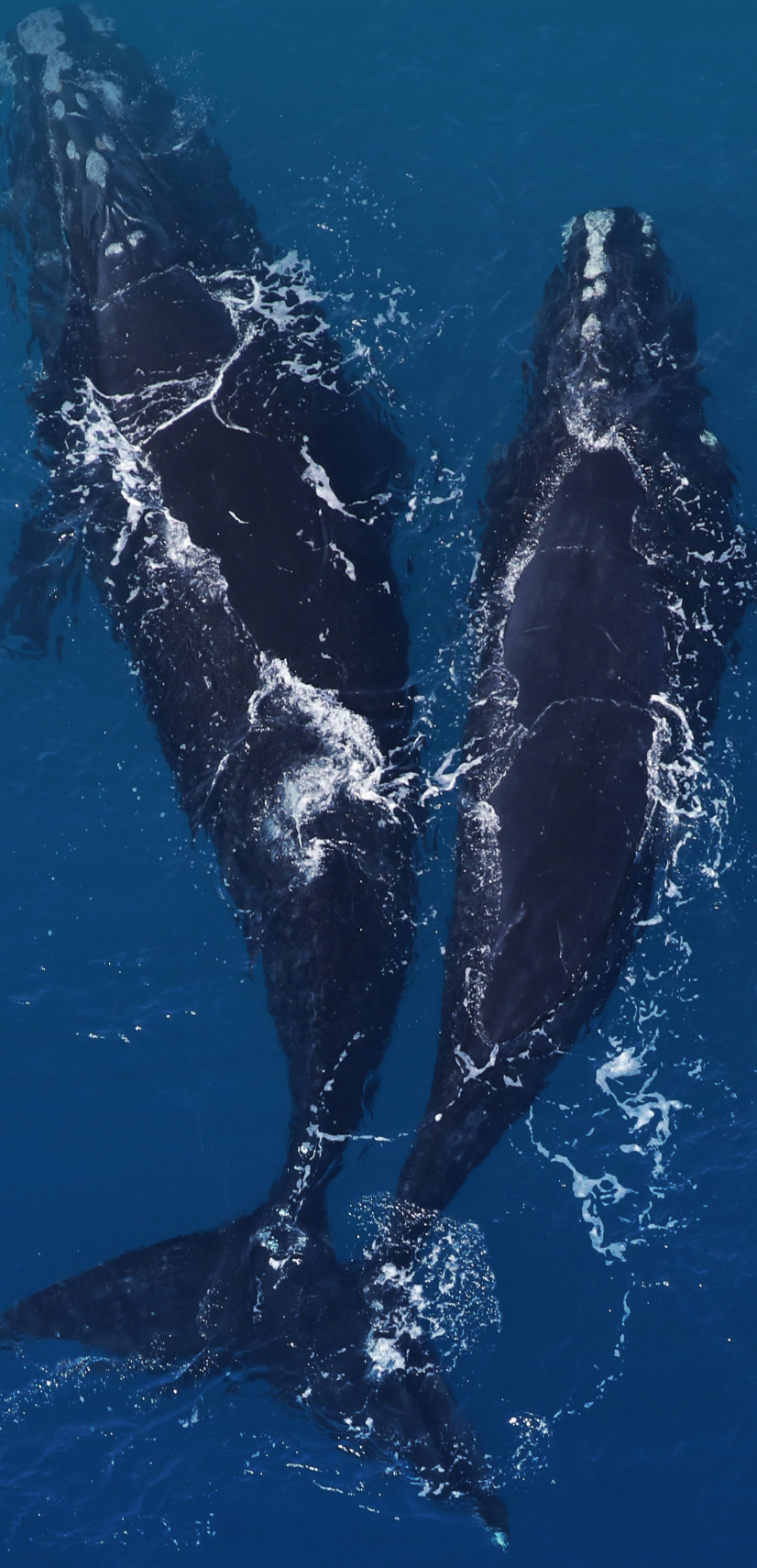




\section{-}

September 2019

Authors: Patrick Mustain,

Whitney Webber, Kim Elmslie,

Gib Brogan and Mariah Pfleger

DOI: 10.31230/osf.io/4mnwp 


\section{Executive Summary}

Punctuation was a grandmother when she was killed in June of 2019 after a vessel collided with her. The North Atlantic right whale matriarch was named for the comma and hyphen-shaped markings on he head that helped researchers identify her. She had been spotted more than 250 times throughout her life as she traveled between calving waters off the southeast coast of the United States and feeding grounds in New England and Canada.

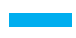

She had been struck by passing vessels before, twice that we know of, but survived. This time the wound was fatal. The injury was so severe that some of her organs were beginning to protrude from a 6 -foot cut on her back. ${ }^{2}$ She had also been entangled in fishing gear at least five separate times. That is five times that she had heavy lines cutting into her flesh, creating scars she would bear to the end of her life. These lines may have dragged lobster traps or crab pots weighing hundreds of pounds. This load would have slowed her down, making her journeys painful and arduous, while also interfering with

Despite the hardships she faced, Punctuation gave birth Despite the hardships she faced, Punctuation gave birth had calves of their own. ${ }^{4}$ Over the years, violent ship strikes and slow, brutal deaths from entanglements in strikes and slow, brutal deaths from entanglements in These deaths make the future of her family lineage bleak.

The story of Punctuation's family is just one of many tragedies unfolding off the Atlantic coast of the U.S. and Canada. The entire North Atlantic right whale population is teetering on the brink of extinction with an alarmingly accelerated decline in recent years. Approximately 400 individuals remain, and less than a quarter of them are breeding females. Every single death increases the urgency with which we must act if these beautiful animals are to have a future. The smaller this population gets, the more difficult it becomes for it to recover. At some point if trends continue, recovery will simply be impossible.
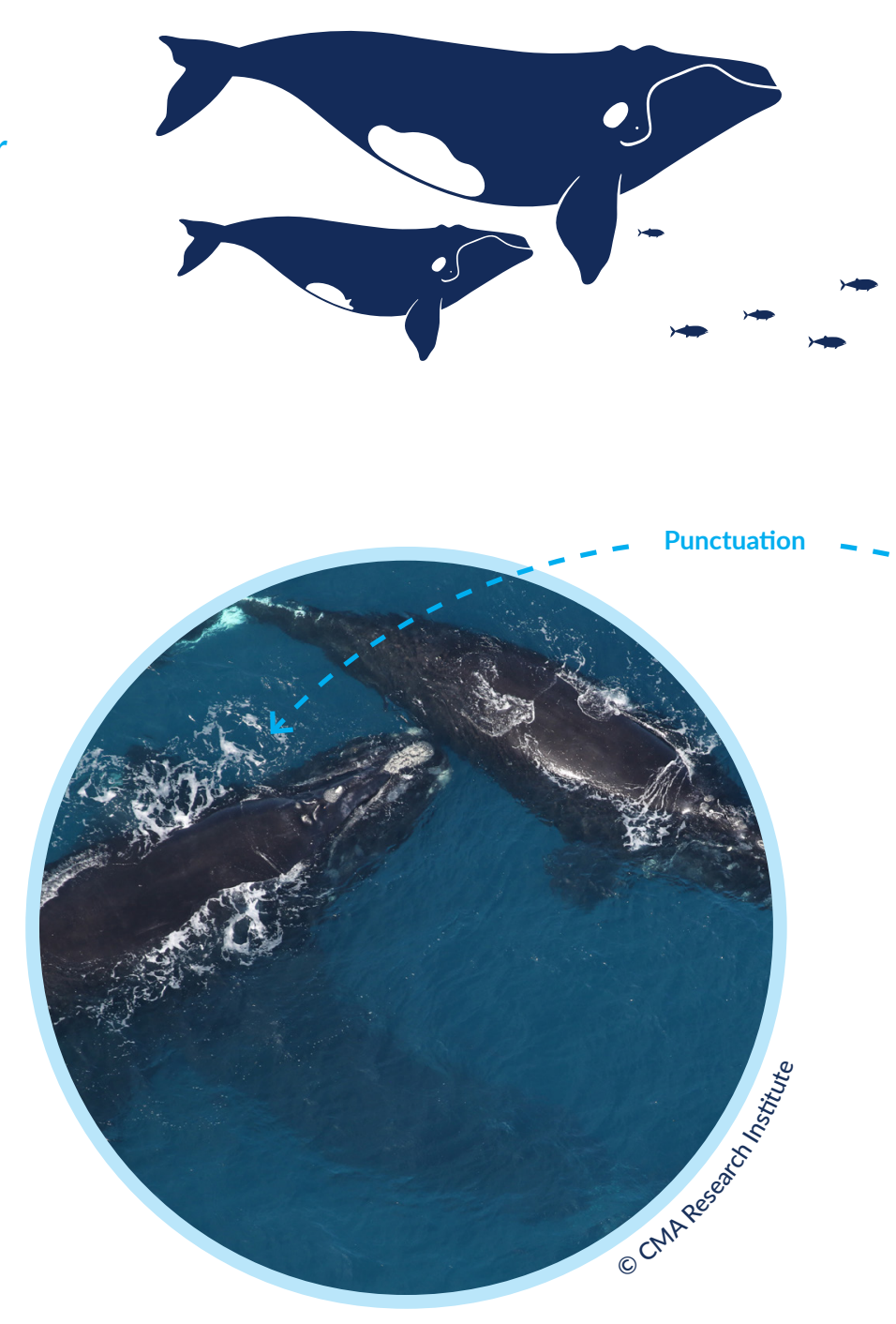

The two greatest threats to North Atlantic right whales are entanglements in fishing gear and collisions with ships. In 2019, researchers looked at the causes of 70 North Atlantic right whale deaths recorded between 2003 and 2018 in the U.S. and Canada. Where the cause of death could be determined, nearly $90 \%$ died as a direct result of fishing gear entanglements or ship strikes. ${ }^{6}$

The U.S. and Canadian governments must act swiftly to halt this catastrophic downturn. If nothing changes, we could see the first large whale go extinct in the Atlantic Ocean in centuries. Protections have worked in the past, but recent deaths make it clear that more needs to be done.
Oceana calls for the following actions to be taken as soon as possible by the U.S. and Canadian governments:

- Reduce the amount of vertical lines used in fixed-gear fisheries in U.S. and Canadian Atlantic waters.

- Implement effective fisheries closures that remove

threats to right whales when they are present.

- Modify fishing gear and practices to reduce the likelihood and severity of entanglements.

- Enhance fisheries monitoring and require public tracking of fishing vessels.

- Enact seasonal speed restrictions in areas where right whales are known to frequent and implement shortterm restrictions in additional areas when they are detected.

Provide long-term funding and capacity building for research, monitoring and risk reduction.

- Expand and strengthen response networks comprising researchers, environmental organizations, industry groups and stakeholders, and government decisionmakers to help manage the crisis and start rebuilding the population.

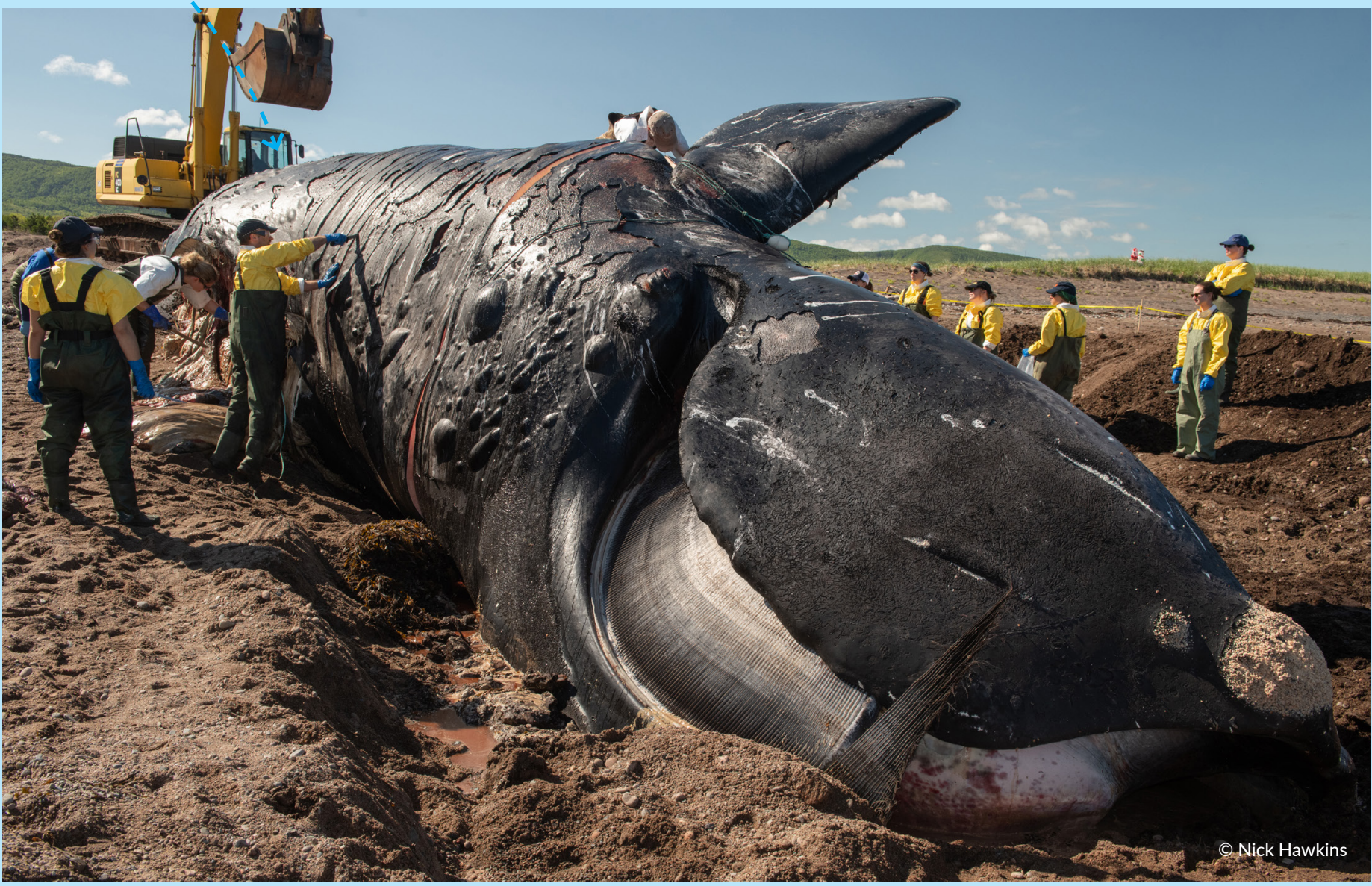




\section{The Right Whale for the Wrong Reasons}

North Atlantic right whales ${ }^{7}$ are said to have been so named because they were often found near shore, swim slowly and tend to float when killed, which made them the "right" whale to

hunt. ${ }^{8}$ And hunted they were, aggressively, until the League of Nations banned whaling for this species in $1935 .{ }^{9}$ The ban was almost too late. By the 1920s, perhaps fewer than 100 of the animals remained. ${ }^{10}$
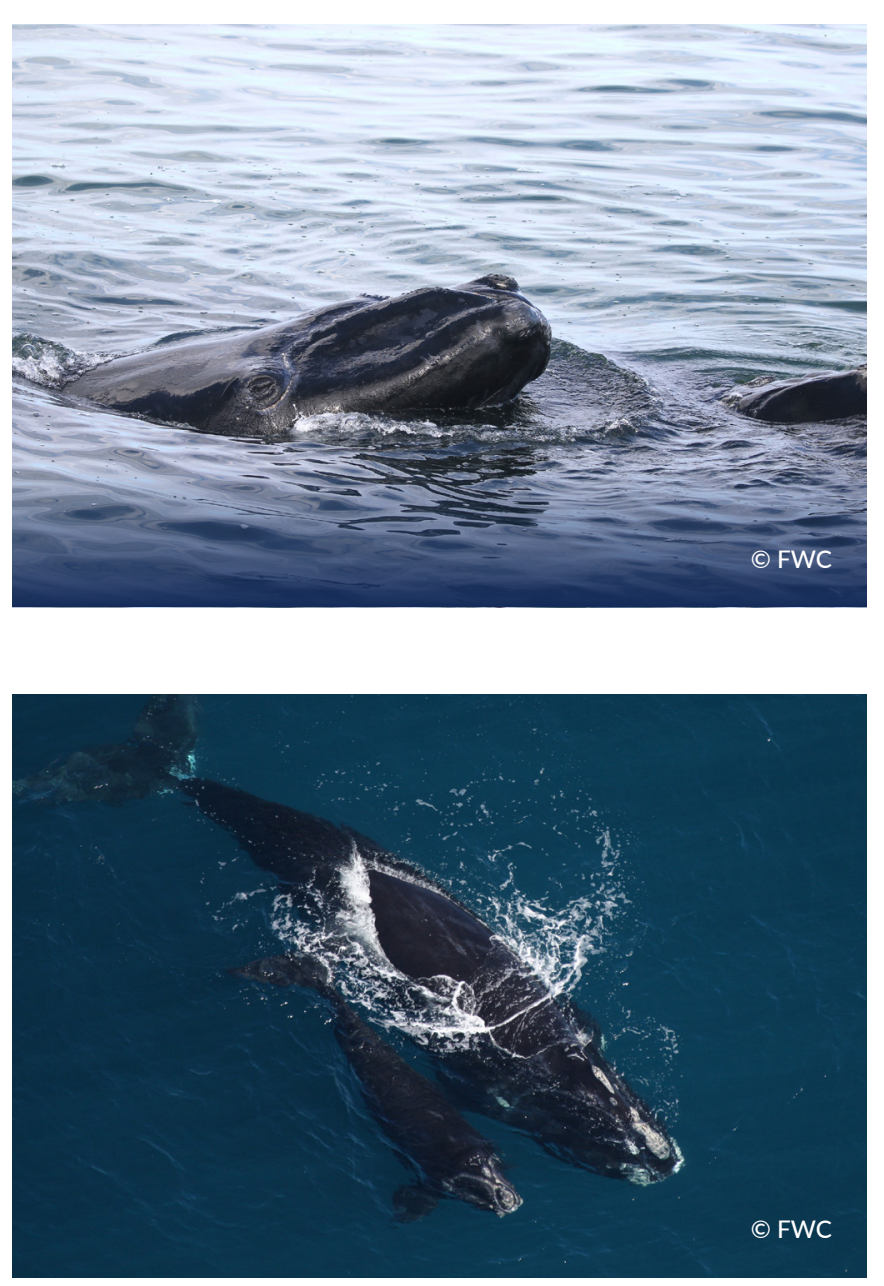

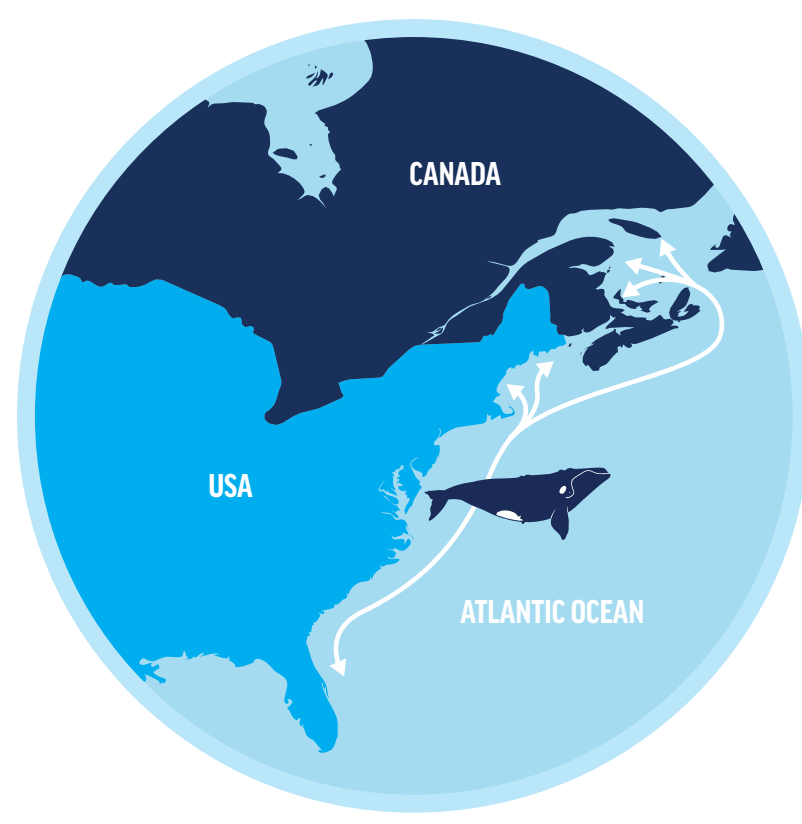

These giants were once found from Bermuda to Canada, across the North Atlantic around Iceland and Norway, and as far south as the northwestern coast of

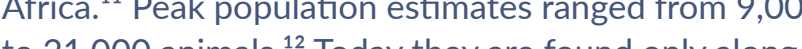
to 21,000 an popla the East Coast of the U.S. and Canada, with occasional sightings in Europe and Iceland. "After the whaling era the population had crept back up to as many as 483 individuals in 2010, but that progress has reversed. ${ }^{14}$ Today, only around 400 animals remain. the last decade continue, extinction is inevitable. ${ }^{16}$

Right whales do not reach reproductive maturity until around 10 years of age. They typically only produce one calf after a year-long pregnancy every three to five years. ${ }^{17}$ However, the trauma caused by chronic fishing gear entanglements and other stressors has now increased the calving interval to every 10 years, and fewer than 100 breeding females remain. ${ }^{19}$ These reproductive challenges are making recovery difficult.

Climate change is adding additional stress to the population, as the distribution of right whales' preferred food - tiny animals called copepods - shift further north as waters warm. ${ }^{20}$ This can add an extra 750 miles $(1,200 \mathrm{~km})$ to the right whales' migration along the Atlantic Coast. Traveling this additional distance can be physically draining, especially for pregnant females. ${ }^{21}$
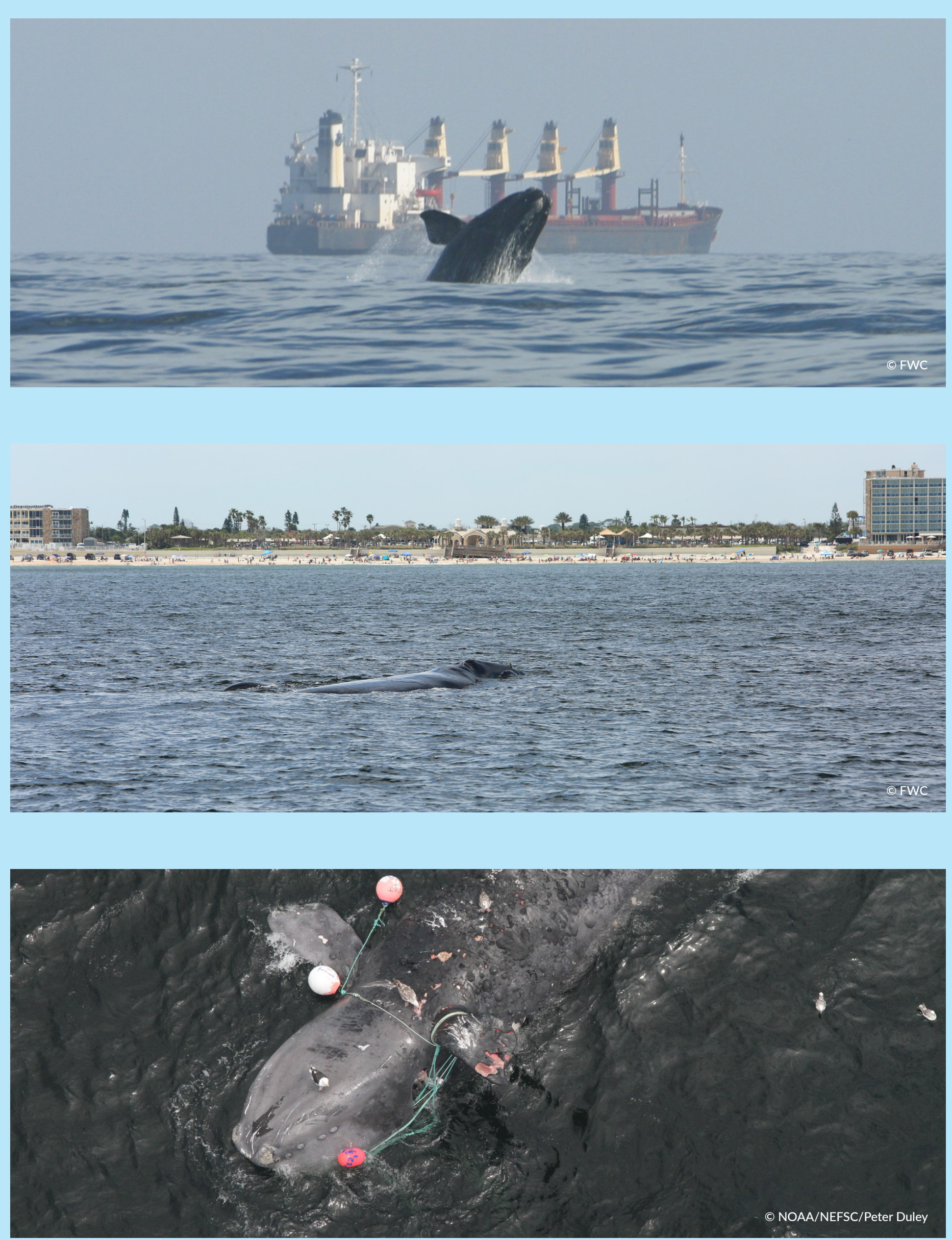
Right whales are on a trajectory toward extinction.

\section{We must act now} to reverse course before it is too late to save them.

\section{Sounding the Alarm}

North Atlantic right whales have been swimming along extinction's cliff for nearly a hundred years, but over the edge. In 2017, after the known deaths of 17 right whales in U.S. and Canadian waters, the U.S. government declared an "unusual mortality event" In 2018, three more whales were found dead in U.S. waters, ${ }^{23}$ and just halfway through 2019, eight more were found dead in Canadian waters.

To put this in perspective, as of August 2019, 28 whales died in less than three years - roughly $7 \%$ of the entire right whale population. This would be like losing more than 560 million people on this planet, over just a few years. But actual mortality is likely much higher since we only observe about $17 \%$ of dead whales - there are many more that die that we never see.
In 2018, U.S. government scientists estimated the number of right whales that can be killed by human actions in a year while still allowing the population to recover. Disturbingly they found that the population can tolerate less than one death per year, or it will not recover ${ }^{26}$ In other words, every single loss threatens the species' recovery. This calculation also depends on right whales reproducing - something we cannot count on every year. In the $2017 / 2018$ calving season, no new calves were spotted. ${ }^{27}$ In the 2018/2019 season, observers saw seven new calves, but this gain was erased by the eight dead adult whales that were found in June and July 2019. 


\section{A Gauntlet of Threats in a Changing Ocean}

Human activities like shipping and fishing continue to put North Atlantic right whales at risk and even more dangers are on the horizon. Continued fishing (with more numerous and ever stronger lines in the water) - along with ship strikes, ocean noise and offshore energy development - all increase the threat to this species.

\section{Fishing}

One of the two leading causes of right whale injury and eath is entanglement in fixed gear used in fisheries for . anchored gillnets with vertical lines connected to buoys floting on the surface, which are used to locate and retrieve the gear. A jungle of roughly 1 million lines sprawls across right whale migration routes and feeding areas in the U.S. and Canada.$^{30}$ These ropes have been seen wrapped around right whales' mouths, fins, tails and bodies. ${ }^{31}$

ishing gear from the U.S. and Canada entangles an estimated 100 right whales each year, and about $83 \%$ of all right whales have been entangled at least once. Between 2010 and 2016, where the cause could be determined, $85 \%$ of right whale deaths were due to entanglement in fishing gear. ${ }^{34}$ The odds of entanglement are increasing by $6.3 \%$ each year due to the right whales' shifting range and exposure to more fishing gear

Whales have been documented dragging lines attached to heavy fishing gear for months - in one case nearly swim, This slows them down, making it difficult to wim, reproduce and feed, and in some cases, can cause life-thre severed fins tails, and cut int are ${ }^{37}$ This is a slow, painfu way to die.
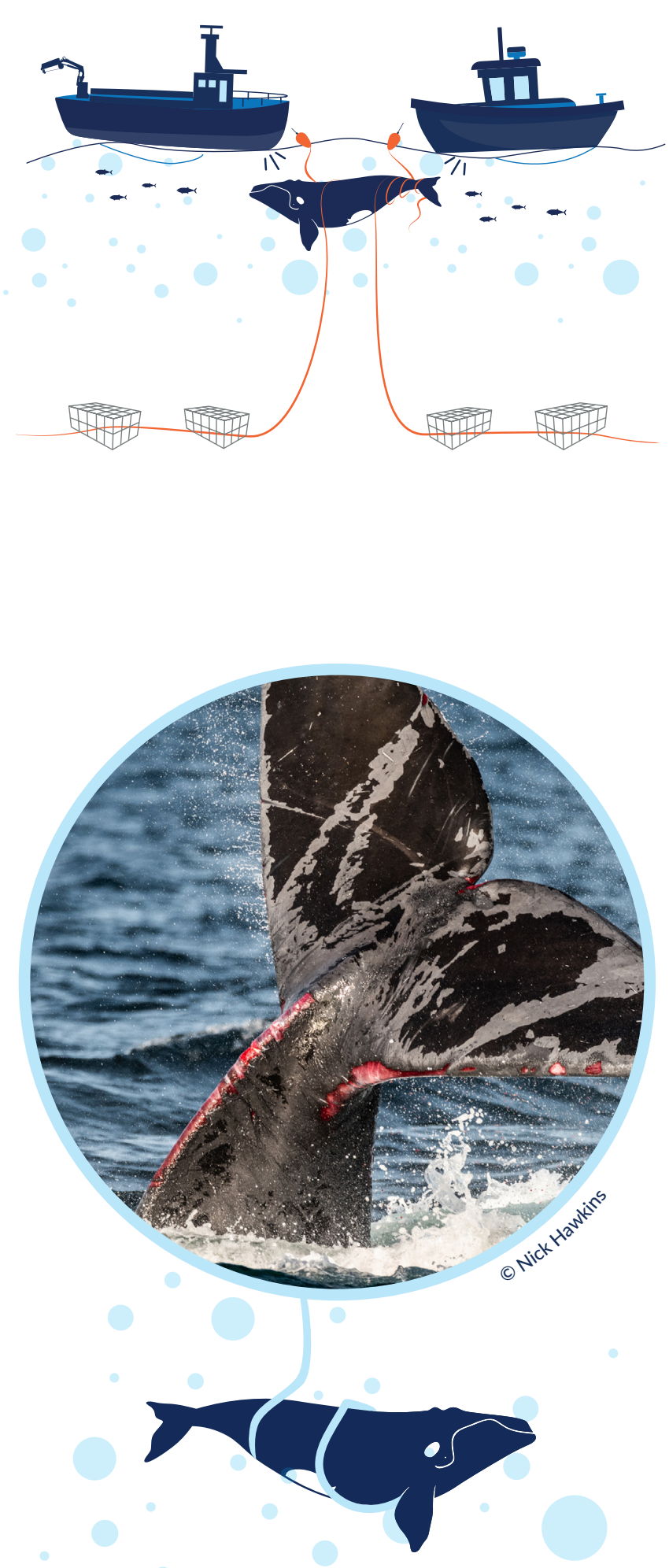

\section{Shipping}

Collisions with ships are the other leading cause of right whale deaths. Right whales are slow, swimming around 6 miles $(9.7$ $\mathrm{km})$ per hour, usually near the water's surface. ${ }^{38}$ They are also dark-skinned and lack a dorsal fin, making them very difficul to spot, especially in unfavorable weather conditions or at major factor in ship-related collisions with right whales." At normal operating speeds, ships cannot maneuver to avoid them, and right whales swim too slowly to be able to move out of the way. This puts right whales at great risk of strikes, which can cause deauly injuries from blunt force trauma or cuts from the propellers. "In addition to ship wrikes, ship noise adds ongoing stress that can affect right whale health.

Of the eight dead right whales found in Canada in June and July 2019, three were deternined to have been killed by ship strikes." This is a wakeup call, demonstrating that current measures to protect right whales from ships are

\section{Emerging Threats}

In addition to the threats from fishing gear entanglements and ship strikes, a wide range of threats from other industria activities are emerging throughout the right whales' range. An expanding "blue economy" will potentially add ther energy installations, offshore aquaculture and 列 sed to to this species. Seismic airgun blasting, a proces creates one of the loudest human-made sounds in the ocean..$^{33}$ In the U.S., the Trump administration plans to allow several companies to perform seismic airgun blasting across huge swaths of right whale habitat. "Experts have warned that the proposed seismic airgun blasting in the Atlantic is likely to have significant, long lasting and widespread poputsions, including the right whate.
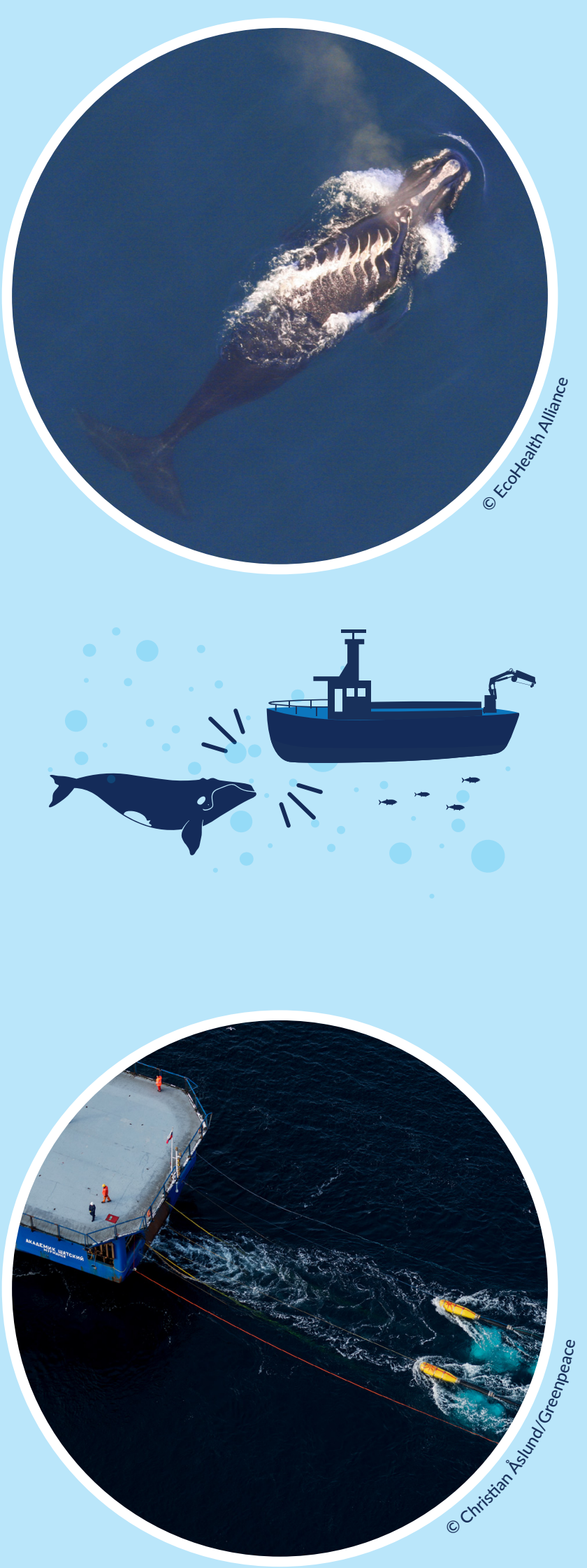


\section{Solutions}

FISHING GEAR ENTANGLEMENTS

To reduce the risk of North Atlantic right whale entanglements in fishing gear, the U.S. and Canadian governments need to reduce the amount of vertical lines used in fixed-gear fisheries in Atlantic waters. Both the U.S. and Canadian governments also need to implement mantive time in are would temporarly close fish seasonally close areas where right whales are known or expected to aggregate. The two governments should work with the fishing industry to explore ways to reduce the number industry to explore ways to reduce the number
of lines in the water, including investing in ropeless technology or other gears that will release upon encounters with large animals like right whales.

\section{SHIP STRIKES}

Science has shown that mandatory season-long speed limits of 10 knots in certain areas reduce lethal ship collision risk levels by $86 \% .{ }^{46} \mathrm{In}$ order to reduce right whale death by ship strike, current seasonal management areas should be extended to new areas where right whales are chould become mandatory. The U. Canadian governments should limit vessel speed to eliminate the threat of ship strikes to right whales and immediately review the possibility of rerouting shipping traffic.
Extinction is forever. We cannot afford to lose this iconic species because of a lack of leadership by governments and industries that are unwilling to change, putting speed, convenience and profit over the right whale's very existence.

\section{EMERGING THREATS}

Seismic airgun blasting and expanding offshore il and gas drilling would wreak havoc on the already struggling right whale population. These Athic should not be allowed off the U.S. Allantic coast. In Atlantic Canada, no seismic activity should occur in right whale habitat. considered to reduce risk to right whales.

\section{TRANSPARENCY}

To enforce and improve fisheries and shipping regulations, managers need to know where ships are located. All fishing and shipping vessels longer than 10 meters (32.8 feet) that operate in right whale habitat should be required to broadcast the Automatic Identification System a puble tracking system that transmits throughout the US and Canadian exclusive though the

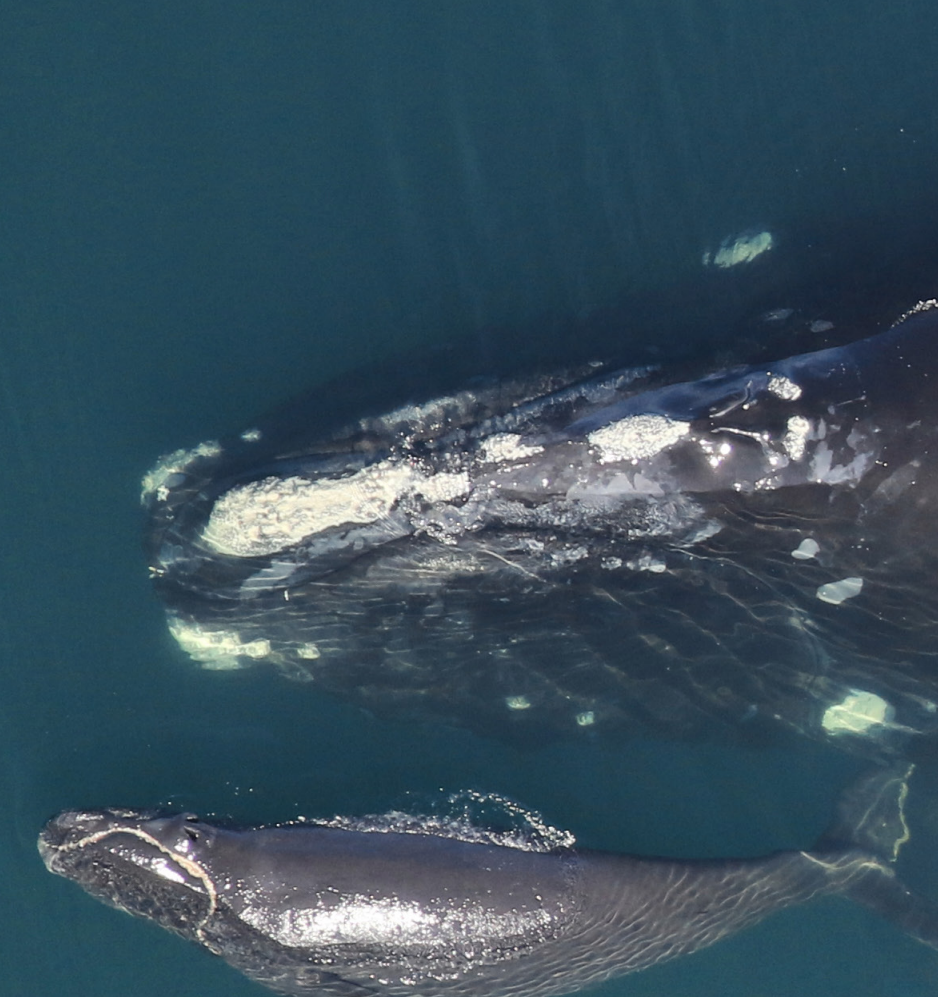




\section{Conclusion}

There is something special about any whale sighting. But when you spot the unmistakable V-shaped spout of a North Atlantic right whale, you are seeing one of the rarest large whales in the
only a few hundred survivors.

Many people have come to treasure the excitement of a right whale sighting along the Eastern Seaboard. But the loss of right wha los wild not would be our loss, and the planet's. We can by and watch as a ar the whe goes extinct for the first time in centuries.

The right whale's plight is dire, but there is hope. The historic low of the population may have been fewer than 100 animals. ${ }^{47}$ Despite this, through the dedicated efforts of conservation organizations. government agencies and marine scientists, right whales were on a fragile course towards recovery reaching a high of almost 500 animals in $2010^{48}$

-

We know that right whales can recover if we stop causing their deaths and allow them to survive and, eventually, to thrive. We need to act swiftly and decisively to end these losses and restore a promising future for the North Atlantic right whale.

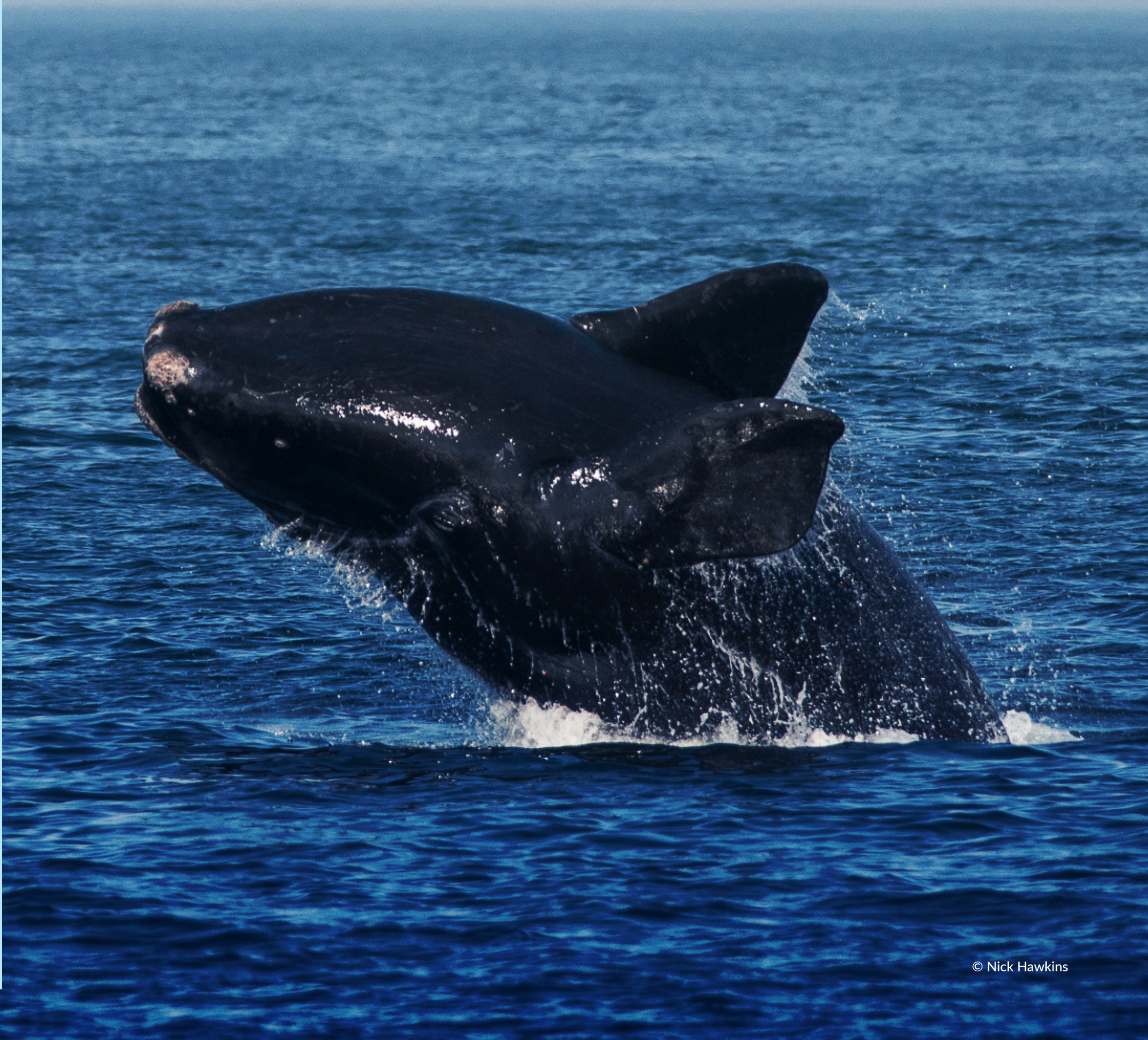




\section{Acknowledgements}

Oceana would like to acknowledge the contributions of three anonymous external reviewers to this report, as well as
Oceana staff including Jacqueline Savitz, Josh Laughren, Beth Lowell, Dustin Cranor, Megan Jordan, Lesley Wilmot, Dr. Katie Oceana staff, including Jacqueline Savitz, Josh Laughren, Beth Lowell, Dustin Cranor, Megan Jordan, Lesley W
Matthews, Dr. Robert Rangeley, Alicia Cate, Ariana Spawn, Lara Levison. Dr. Sarah Giltz and Diane, Hoskins.

Note: All photos of living North Atlantic right whales were taken under permits from NOAA or Fisheries and Oceans Canada.

\section{References}

${ }^{1}$ New England Aquarium Right Whale Found Dead in the Gulf of St. Lawrence Identified As Punctuation. In. Center For Ocean blog/1281rightwhaledeath/. Accessed Jul 30, 2019

'Coletta A (2019) Two percent of the world's North Atlantic right whales have died in the last two months. Washington Post. Available: https:// www.washingtonpost.com/world/the_americas/two-percent-ofthe-worlds-north-atlantic-right-whales-have-died-in-the-last-twostoryhtml Accessed Aus 88 2019.

St Lawrence Identifed As Punctuation In: Cead in the Gulf of Life. Available: https://www.andersoncabotcenterforococanlife.org/ blog/1281rightwhaledeath/. Accessed Jul 30, 2019.

'Hagbloom M Punctuation's Calf. In: Center For Ocean Life. Available: https://www.andersoncabotcenterforoceanlife. org//blog/1068/

“ Sharp S, McLellan W, Rotstein D, et al. (2019) Gross and histopathologic diagnoses from North Atlantic right whale Eubalaena glacialis 135: 1-31. doi: 10.3354 /dao03376.

'There are three distinct species of right whale: the North Atlantic right whale, the North Pacific right whale, and the southern right whale. Unless noted otherwise, throughout this report the term "right whale" refers to the North Atlantic right whale

Isses RL30907.

'Van Drimmelen, B., 1991. The International Mismanagement of

Whaling. UCLA Pac. Basin L, 10, p.240.

Marine Mammal Commission. Species of Concern Profile North Atlantic Right Whale. Available at https://www.mmc.gov//Pro
species-of-concern/north-atlantic-right-whale/.

species-of-concern/north-atlantic-right-whale/. . Issues. Libray
RL30907.

Monsarrat S, Pennino MG, Smith TD, et al. (2016) A spatially explicit estimate of the prewhaling abundance of the endangered North Atlantic right whale: Eubalaena glacialis Historical Abundance. Conservation Biology 30: 783-791. doi: 10.1111/cobi.12664 Buck

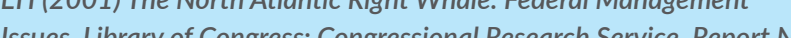
Issues. Libriyc
RL30907.
${ }^{13}$ National Marine Fisheries Service (2019) North Atlantic Right Whale (Eubalaena glacialis: Western Atlantic Stock. NOAA. "Aace RM, Corkeron PJ and Kraus SD (2017) State-space mark-recaptu estimates reveal a recent decline in abundance of North Atlantic right whales. Ecology and Evolution 7: 8730-8741. doi: 10.1002/ ece3.3406. Pettis, HM, Pace RM III, Hamilton, PK. 2018. North Atlantic Right Whale Consortium 2018 Annual Report Card. Report to the North Atlantic Right Whale Consortium. www.narwc.org. Renge Shifts Necessitate Advanced Policy Planning The Species the North Atlantic Right Whale. Oceanography 31 doi: 10.5670 oceanog.2018.209.

"Kraus SD, Hamilton PK, Kenney RD, Knowlton AR and Slay CK (2001) Reproductive parameters of the North Atlantic right whale. J. Cetacea

Res. Manage. (Special Issue)e. 2: 231-236.
Pettis HM, Pace RM, Schick RS, Hamilton PK. 2017. North Atlantic Right Wiale Consortic North Atlantic Right Whale Consortium, October 2017, amended 8-182018. https://www.narwc.org/report-cards.htm. Pettis, HM, Pace RM III, Hamilton, PK. 2018. North Atlantic Right Whale Consortium 2018 Annual Report Card. Report to the North Atlantic Right Whale Consortium. Wiw.narwe.org. Record N, Pendleton D, Bach W, et al. (2019) Rapid ClimateDriven Circulation Changes Threaten Conservation of Endangered oceanog.2019.201

Rolland R, Schick R, Pettis H, et al. (2016) Health of North Atlantic right whales Eubalaena glacialis over three decades: from individual health to demographic and population health trends. Marine Ecology Progress Series 542: 265-282. doi: 10.3354/meps11547.

NOAA Fisheries (2019) 2017-2019 North Atlantic Right Whale Una event. Accessed Jul 30, 2019

Pettis, HM, Pace RM III, Hamilton, PK. 2018. North Atlantic Right Whale Consortium 2018 Annual Report Card. Report to the North Atlantic Right Whale Consortium. www.narwc.org. MacDonald M (2019) Canada's shipping industry under the microscope as whale death toll grows| The Star. In: thestar.com. Available: https://

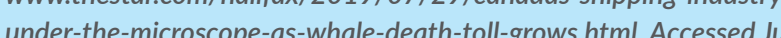
31, 2019.

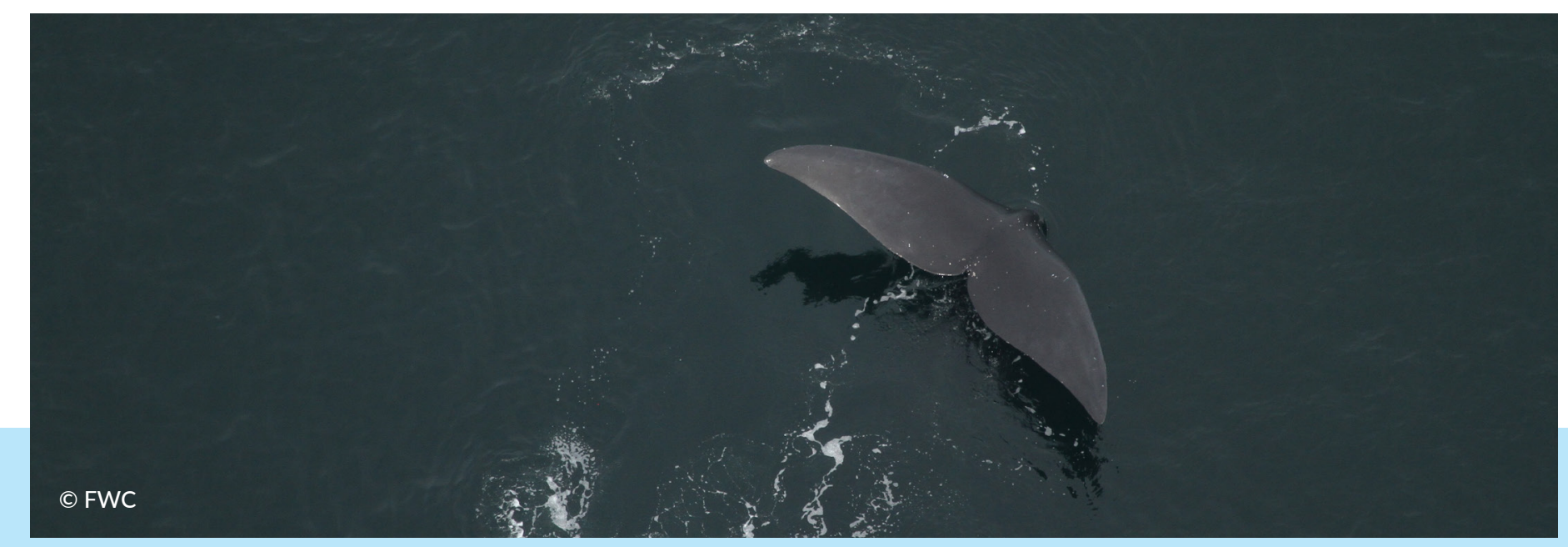

${ }^{2}$ Kraus SD, Brown MW, Caswell H, Clark CW and others (2005) North Atlantic right whales in crisis Science 309: 561-562. National Marine Fisheries Service (2019) North Attantic Right Whale (Eubalaena glacialis): Western Atlantic Stock. NOAA.

Pettis, HM, Pace RM III, Hamilton, PK. 2018. North Atlantic Right Whale Consortium 2018 Annual Report Card. Report to the North Atlantic Right Whale Consortium. www.narwc.org

MacDonald M (2019) Canadas shipping industry under the microscope as whale death toll grows I The Star. In: thestar.com. Available: https: actersed the $31,2019$.

"Pettis, HM, Pace RM III, Hamilton, PK. 2018. North Atlantic Right Whale Consortium 2018 Annual Report Card. Report to the North Atlantic Right Whale Consortium. www.narwc.org; Pettis HM, Pace RM Schick RS, Hamilton PK. 2017. North Allantic Right Whale Consorti 2017 annual report card. Boston MA. North Atlantic Right Whale Whare Consortium Octopr 2017, amended 8-18-2018. https /ww narwc.org/report-cards.htm

Hayes SA, Gardner S, Garrison L, Henry A and Leandro L (2018) North Atlantic Right Whales- Evaluating Their Recovery Challenges in 2018. NOAA Technical Memorandum NMFS-NE-247: 30. Cassoff R, Moore K, McLellan W, et al. (2011) Lethal entanglement in baleen whales. Dis. Atlantic Right Whales- Evaluating Their Recover Challenges in 2018 NOAA Technical Memorandum NMFS-NE-247: 30.

Knowlton AR, Hamilton PK, Marx MK, Pettis HM, Kraus SD

(2012) Monitoring North Atlantic right whale Eubalaena glacialis entanglement rates: a 30 yr retrospective. Mar Ecol Prog Ser 466:293

Sharp S, Melellan W, Rotstin D, et al. (2019) Gross and (a) Organisms 135: 1-31. doi: 10.3354/dao03376.

${ }^{35}$ Hayes SA, Gardner S, Garrison L, Henry A and Leandro L (2018) North Atlantic Right Whales- Evaluating Their Recovery Challenges in 2018. NOAA Technical Memorandum NMFS-NE-247: 30 . NOAA Fisheries (2018) Young Right Whale Likely Died from Entanglement | NOAA Fisheries. Available: / feature-story/young-

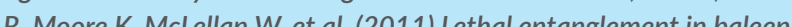

whales. Diseases of Aquatic Organisms 96: 175-185. doi: 10.3354/ dao02385. in baleen whales. Diseses

Hain JHW, Hampp JD, McKenney SA, Albert JA and Kenney RD (2013) Swim Speed, Behavior, and Movement of North Atlantic Right Whales (E)baleena, Ropert-Coudert Y, edhor PLos ONE 8 e 73 Fed 19860

. histopathologic diagnoses from North Atlantic right whale Eubalaena glacialis mortalities between 2003 and 2018. Diseases of Aquatic Organisms 135: 1-31. doi: 10.3354/dao03376.

Rolland RM, Parks SE, Hunt KE, et al. (2012) Evidence that ship noise increases stress in right whales. Proceedings of the Royal Society B: “MacDonald M (2019) Canad's shipping industry under the microso as whale death toll grows I The Star. In: thestar.com. Available: $h$ ttps:// under-the-microscope-as-whale-death-toll-grows.html. Accessed Ju 31, 2019.

Hildebrand JA (2009) Anthropogenic and natural sources of ambient noise in the ocean. M5 Marassment Authorizations related to Taking Ocean 83 FR 63268 December 7, 2018.

Letter from 75 Scientists to President of the United States (Mar. 5 , 2015). Available at: http://usa.oceana.org/sites/default/files/75 marine_scientist_letter-sesismic.pdf. . collision-related mortality for North Atlantic right whales. Ecosphere 4

政

species-of-concern/north-atlantic-right-whale/.

Pace RM, Corkeron PJ and Kraus SD (2017) State-space mark-recapture estimates reveal a recent decline in abundance of North Atlantic right whales. Ecology and Evolution 7.8730-8741. doi: 10.1002
Cassoff $R$, Moore K, McLellan W, et al. (2011) Lethal entanglement Right Whale. Available at https://www.mmc.gov/priority-topics/ 


\title{
oceana
}

\author{
oceana.org
}

